African Crop Science Journal by African Crop Science Society is licensed under a Creative Commons Attribution 3.0 Uganda License. Based on a work at www.ajol.info/ and www.bioline.org.br/cs DOI: https://dx.doi.org/10.4314/acsj.v29i2.2

\title{
MANAGEMENT OF Lasiodiplodia theobromae, THE CAUSAL AGENT OF MANGO TREE DECLINE DISEASE IN GHANA
}

\author{
F.K. ABLORMETI, S.R. COLEMAN ${ }^{1}$, J.O. HONGER ${ }^{2}$, E. OWUSU ${ }^{1}$, I. BEDU ${ }^{2}$, O.F. AIDOO ${ }^{3}$, \\ E.W. CORNELIUS ${ }^{4}$ and G.T. ODAMTTEN ${ }^{1}$
}

Council for Scientific and Industrial Research-Oil Palm Research Institute, Coconut Research Programme, P. O. Box 245, Sekondi-Takoradi, Ghana

${ }^{1}$ Department of Plant and Environmental Biology, College of Basic and Applied Sciences, University of Ghana, P. O. Box LG 55, Legon, Ghana

${ }^{2}$ Soil and Irrigation Research Centre, College of Basic and Applied Sciences, University of Ghana, P. O. Box LG 68, Legon, Ghana

${ }^{3}$ Department of Biological, Physical and Mathematical Sciences, School of Natural and Environmental Sciences, University of Environment and Sustainable Development, PMB, Somanya, Ghana

${ }^{4}$ Department of Crop Science, College of Basic and Applied Sciences, University of Ghana, P. O. Box LG 44, Legon, Ghana

Corresponding author: fablormeti@yahoo.com

(Received 9 November 2020; accepted 6 May 2021)

\begin{abstract}
Mango (Mangifera indica L.), is one of the economically most important crops in Ghana. It is recognised for its popularity in contributing to food and nutritional security. Despite its economic importance, mango tree decline disease, caused by Lasiodiplodia theobromae, poses a serious threat to the mango industry in the country. The objective of this study was to evaluate fungicides (i.e., carbendazim, zamir, mancozeb, funguran and sulphur 80) and bio pesticides (Chromolaena odorata, Azadirachta indica and Carica papaya) against L. theobromae. The results showed that all the tested fungicides, except for sulphur 80, inhibited mycelial radial growth of $L$. theobromae, with carbendazim and funguran improving the vegetative growth of the shoots and leaves in the field. Mango trees treated with carbendazim, after the third spray, had no disease symptoms. However,

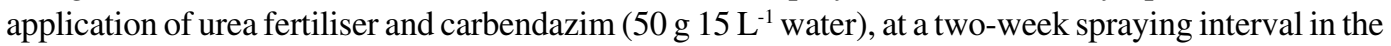
field, reduced the severity of $L$. theobromae. Application of biopesticides (plant extracts) showed that $C$. odorata had the highest efficacy, followed by $A$. indica and then $C$. papaya. Although further studies on plant extracts in the field are required, our findings provide important information for the development of integrated management strategies for the pathogen, and the disease it transmits.
\end{abstract}

Key Words: Azadirachta indica, bioextract, Carica papaya, Chromolaena odorata, Lasiodiplodia theobromae 
La mangue (Mangifera indica L.) est l'une des cultures les plus importantes économiquement au Ghana. Il est reconnu pour sa popularité en contribuant à la sécurité alimentaire et nutritionnelle. Malgré son importance économique, la maladie du déclin du manguier, causée par Lasiodiplodia theobromae, constitue une menace sérieuse pour l'industrie de la mangue dans le pays. L'objectif de cette étude était d'évaluer les fongicides (c'est-à-dire le carbendazime, le zamir, le mancozèbe, le fonguran et le soufre 80) et les pesticides biologiques (Chromolaena odorata, Azadirachta indica et Carica papaya) contre L. theobromae. Les résultats ont montré que tous les fongicides testés, à l'exception du soufre 80, inhibaient la croissance radiale mycélienne de L. theobromae, le carbendazime et le fonguran améliorant la croissance végétative des pousses et des feuilles au champ. Les manguiers traités au carbendazime après la troisième pulvérisation ne présentaient aucun symptôme de maladie. Cependant, l'application d'engrais à base d'urée et de carbendazime (50 g $15 \mathrm{~L}^{-1}$ d'eau $)$ à un intervalle de pulvérisation de deux semaines dans le champ a réduit la gravité de L. theobromae. L'application de biopesticides (extraits de plantes) a montré que $C$. odorata avait la plus grande efficacité, suivie par $A$. indica et ensuite $C$. papaya. Bien que des études supplémentaires sur les extraits de plantes sur le terrain soient nécessaires, nos résultats fournissent des informations importantes pour le développement de stratégies de gestion intégrée du pathogène et de la maladie qu'il transmet.

Mots Clés: Azadirachta indica, bioextrait, Carica papaya, Chromolaena odorata, Lasiodiplodia theobromae

\section{INTRODUCTION}

Mango (Mangifera indica L.) is an economically valuable crop, with an annual output of over 30 million metric tonnes of fruit from the top producing countries (India and China) (Evans et al., 2017). It is produced in tropical and sub-tropical regions (Krishnan et al., 2009) with over 30 varieties globally (Tharanatan et al., 2006). Currently, the crop is one of the Ghanaian major non traditional fruits for export (Zakari, 2012); thus, it is projected to be a major potential foreign exchange earner in the next decade (Okorley et al., 2014). Ghana's mango production and export portfolio have increased dramatically, from 23,000 metric tonnes in 1991 to 983 , 000 metric tonnes in 2007 (Yidu, 2015). Mango production and mango-related activities significantly contribute to employment creation and poverty reduction in rural and urban economies worldwide (Banson and Yawson, 2014; Akurugu et al., 2016).

Mango tree decline disease (MTDD) (Coleman, 2016); is one of the economically important diseases, posing a serious threat to the survival and sustainability of the mango orchards in Ghana (Ablormeti, 2016; Coleman, 2016; Honger et al., 2018). The disease was first reported in Brazil in 1945, with $60 \%$ infestation (Ploetz et al., 1996) and elsewhere, several million mango trees have been killed by the disease (Schaffer, 1994; Ramos et al., 1997; Simone, 1999; Al Adawi et al., 2003). The disease is caused by Lasiodiplodia theobromae (Syn: Botryodiplodia theobromae) (Ablormeti, 2016; Coleman 2016; Honger et al., 2018). Mango tree decline disease is characterised by gummosis from the bark, bark splitting, streaking and vascular discolouration beneath the bark. Rotten canker is commonly observed on severely affected trunks, which sometimes results in exudation of liquid with offensive smells (Masood et al., 2010). Under similar conditions, the vascular bundles block, preventing the translocation of nutrients leading to high mortality of trees (Khuhro et al., 2005). Eventually, the tree dieback and progresses to the larger branches, leading to subsequent death of the tree (Al-Adawi et al., 2006; Saeed and Masood, 2008). 
Chemical fungicides have been widely used to control plant pathogens, including Sclerotinia stem rot (Bradley et al., 2006), wheat stem rust (Wanyera et al., 2009), rice diseases (Groth et al., 1990), net blotch and spot-type net blotch (Jayasena et al., 2002), rice blast disease (Yamaguchi, 1982), dying back disease of mango (Javiaid et al., 2008) and MTDD or sudden decline disease of mango (Masood et al., 2014; Saeed et al., 2017; Sahi et al., 2012; Shahbaz et al., 2009). Also, several studies have evaluated the efficacy of different plant extracts against plant pathogens (Tegegne et al., 2008; Gurjar et al., 2012; Sales et al., 2016; Okemo et al., 2003). However, only a few studies have assessed the effectiveness of plant extracts against the quick sudden decline of mango (Sahi et al., 2012). Therefore, the objective of this study evaluates the efficacy of different chemical fungicides and plant extracts as a basis for developing biocontrol strategies.

\section{MATERIALS AND METHODS}

Stock cultures. The pure culture of $L$. theobromae was isolated from various parts of affected mango trees (barks, leaves and branches). Stock cultures of the isolated fungus were grown on $90 \mathrm{~mm}$ petri dishes. The cultures were stored in incubators at 28 $\pm 1{ }^{\circ} \mathrm{C}$ and sub-cultured every 3 weeks for further analysis.

Selected fungicides. Five fungicides used for the study were grouped into two categories based on their efficacy, i.e., protectant and systemic fungicides. The protectant fungicides comprised of zamir, mancozeb, funguran and sulphur 80; whereas the systemic fungicide was carbendazim. The trade name, active ingredients, mode of action and various levels of concentration of the fungicides are listed in Table 1.

In vitro fungicide evaluation. The protectant and systemic fungicides were used for in vitro screening by food poison technique (Kiran $e t$

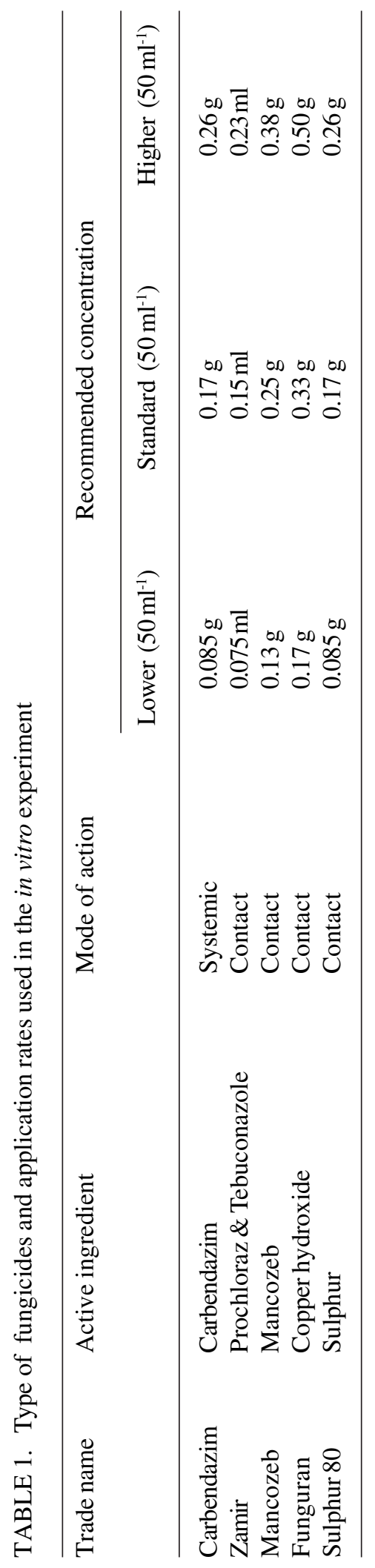


al., 2010), using potato dextrose agar (PDA). Inoculum of $4 \mathrm{~mm}$ agar discs was obtained from the advancing margin of the culture on PDA. The experiment was conducted in completely randomised design (CRD), with three concentrations each per fungicide; and was incubated under controlled conditions of temperature $\left(23-31{ }^{\circ} \mathrm{C}\right)$ and relative humidity (60-70\%). Each fungicide treatment was replicated three times. The plates were observed daily, and colony diameters of the fungus of each treatment with control, were recorded with a metric ruler $(\mathrm{mm})$, until the fungus of control treatment fully occupied the area of the petri dish. The percentage reduction in radial growth (I) over control was calculated using the formula proposed by Kiran et al. (2010):

$1=\frac{\mathrm{C}-\mathrm{T}}{\mathrm{C}} \times 100$

Where:

I = Percent reduction in growth of test fungi; $\mathrm{C}=$ Radial growth $(\mathrm{mm})$ in control; and $\mathrm{T}=$ Radial growth $(\mathrm{mm})$ in treatment.

Field evaluation of fungicides. The experiment was conducted in a mango plantation at Savelugu Nanton Municipality in the Northern Region of Ghana. The farm was a hotspot for MTDD, with mango trees showing high disease incidence. The experiment was conducted using a randomised complete block design (RCBD) with four replicates. Mancozeb, Funguran and Carbendazin which inhibited L. theobromae in vitro, were selected and used for the field experiment (Table 2). Prior to the study, selected disease-trees for the trial were pruned to remove dead branches and plant residues from the field. Five plants of approximately the same age, height and canopy were selected per fungicide treatment. Then the plants were sprayed with fungicide for two months, twice a month.

The treated and control plants were provided with urea fertiliser at a rate of $870 \mathrm{~g}$ per tree, based on the manufacturer's recommendation. We used the ring method for fertiliser application, and the plants were irrigated every two days until the end of the trial. The effects of the fungicides on mango plants were evaluated by assessing the disease severity before and after treatment (Panhwar et al., 2007); where $0=$ No signs of the disease, $1=$ Gum traces oozed out/few smaller branches dried, 2 = Oozing of gums/bark splitting and few dead branches, $3=\mathrm{Up}$ to $35 \%$ of tree dead, $4=$ More than $35 \%$ of the tree dead, $5=$ Foliage of whole tree wilted. Data were collected on vegetative growth (i.e., new shoots and leaves) bi-monthly after each fungicidal treatment. The trade name, active ingredients, mode of action and concentration of the fungicides are listed in Table 2.

\section{In vitro evaluation of bioextracts}

Plant materials used. The common name, scientific name, family name and the plant part used are listed in Table 3. Acheampong/Siam weed, neem, pawpaw were used for the botanical assay. The plants were obtained from the University of Ghana campus and its

TABLE 2. Fungicides, mode of action and their recommended concentration used in field control

\begin{tabular}{lllc}
\hline Trade name & Active ingredient & Mode of action & Concentration $\left({\left.\mathrm{g} 15 \mathrm{~L}^{-1}\right)}^{-1}\right.$ \\
\hline Carbendazim & Carbendazim & Systemic & 50 \\
Mancozeb & Mancozeb & Contact & 50 \\
Funguran & Copper hydroxide & Contact & 100 \\
\hline
\end{tabular}


TABLE 3. Common names, scientific names, family names and part used for in vitro bioextract control

\begin{tabular}{llll}
\hline Common name & Scientific name & Family name & Part used \\
\hline Siam/Acheampong weed & Chromolaena odorata & Asteraceae & Leaves \\
Neem & Azadirachta indica & Meliaceae & Leaves \\
Pawpaw & Carica papaya & Caricaceae & Seeds \\
\hline
\end{tabular}

suburbs. The identity was confirmed at the University of Ghana Herbarium, Department of Plant and Environmental Biology.

Preparation of aqueous plant extracts. The plant materials were fragmented into pieces and air dried for a week. One kilogramme each of the dried plant materials was taken and pulverised into powder using a commercial milling machine (Fritsch Company, Germany). A total of $200 \mathrm{~g}$ of each of the powdered samples were taken into $1 \mathrm{~L}$ conical flask; $1 \mathrm{~L}$ distilled water was added, and allowed to stand for 12 hours. The supernatant was then strained through a clean white muslin cloth to obtain the extracts.

Inoculation and incubation of the organism. For both solid and liquid cultures, we used an inoculum of $4 \mathrm{~mm}$ agar discs obtained from the growing edge of the culture on potato dextrose agar (PDA), with three replicates in each preparation. Inoculated petri plates and flasks were incubated at $28 \pm 1{ }^{\circ} \mathrm{C}$.

In vitro aqueous extracts treatments. The potency of aqueous extracts of the selected plants materials ( $C$. odorata leaves, $A$. indica leaves and $C$. papaya seeds) inhibiting the growth of the pathogen was tested. Growth of the fungus was assessed on solid DPDA and in liquid DPDB, amended with varying concentrations $(1: 1,1: 2,1: 5$ and $1: 10 \mathrm{v} / \mathrm{v}$ dilutions) of the extracts. Petri plates and flasks containing the amended media of the appropriate dilutions in triplicates, were inoculated with the fungus and incubated. Also, control plates and flasks containing extractfree PDA and PDB were inoculated with the fungus.

Assessment of growth and sporulation. Radial growth of cultures of $L$. theobromae, on solid media in Petri dishes was assessed by measuring the diameter of cultures along two diameters, drawn at the bottom of the petri dishes, through the centre of the inoculated disc. The mean of the two measured diameters was calculated and used to determine radial growth rate. Growth in liquid cultures was assessed by estimating the dry weight of the harvested mycelial mat at the end of the incubation period. Mycelia collected on a previously weighed and dried Whatman No. 1 filter paper was dried at $75^{\circ} \mathrm{C}$ for $24 \mathrm{hr}$. The filter paper carrying the dried mycelia was then weighed, after cooling in a desiccator to obtain a constant dry weight. The dried weight of the mycelia was obtained by the difference in weight between the filter paper alone and the filter paper carrying the dried mycelia. For the assessment and estimation of sporulation, 4 $\mathrm{mm}$ agar discs was mounted in lactophenol and observed under light microscope. The number of spores per 20- 25 microscope field views was counted and recorded.

Data analysis. The data collected were analysed using analysis of variance (ANOVA). In cases where there were significant differences $(\mathrm{P}<0.05)$, means were separated using the least significant difference (LSD) of GENSTAT version 19.1. 


\section{RESULTS}

In vitro screening of fungicides. Results from the laboratory bioassay showed that all the fungicides, except sulphur 80, induced complete inhibitions $(100 \%)$ of mycelia radial growth (Table 4). There was no significant $(\mathrm{P}>0.05)$ difference in mycelia radial growth of the fungus on the second day at various concentrations of sulphur 80 . However, days three and four showed significant differences $(\mathrm{P}>0.05)$ in growth on the standard $(\mathrm{P}<0.05)$ and the other concentrations (day 3 and day $4, \mathrm{P}<0.05)$.

In vivo assessment of incidence and severity. Fungicides which were able to inhibit the radial growth of $L$. theobromae under in vitro condition were selected for the field trial (i.e., carbendazim, mancozeb and funguran). The results showed a reduction in fungal infection in treated mangoes, whereas, the incidence (Fig. 1A) and severity (Fig. 1B) increased in untreated (control) trees with time. Two weeks after the second fungicidal spray, carbendazim and funguran were effective against the fungus (Fig. 1 B). Trees treated with carbendazim after the third spray had no visible disease symptoms; however, mango trees treated with mancozeb showed some gum exudation. Evidently carbendazim was the most highly effective fungicide, followed by funguran and then mancozeb.

\section{Fungicidal spray on shoot and leaf growth.} The number of shoots and leaves of diseasetrees increased significantly $(\mathrm{P}<0.05)$ across all treatments, when the fungicides were sprayed at a two-week interval (Fig. 1C and 1D). Leaf and shoot growth steadily increased until the end of the experiment. Mango plants treated with carbendazim produced the highest number of leaves; followed by funguran and then mancozeb. After the 3rd spray, the

TABLE 4. Inhibition of mycelial radial growth of L. theobromae on potato dextrose agar amended with six fungicides

\begin{tabular}{|c|c|c|c|c|}
\hline \multirow[t]{2}{*}{ Fungicide } & \multirow[t]{2}{*}{ Concentration } & \multicolumn{3}{|c|}{ Inhibition of mycelial radial growth (\%) } \\
\hline & & Day 2 & Day 3 & Day 4 \\
\hline Carbendazim & $\begin{array}{l}0.09{\mathrm{~g} \mathrm{~s} 50 \mathrm{ml}^{-1}}_{0.17 \mathrm{~g} 50 \mathrm{ml}^{-1}} \\
0.26 \mathrm{~g} 50 \mathrm{ml}^{-1}\end{array}$ & $\begin{array}{l}100 \mathrm{a} \\
100 \mathrm{a} \\
100 \mathrm{a}\end{array}$ & $\begin{array}{l}100 \mathrm{a} \\
100 \mathrm{a} \\
100 \mathrm{a}\end{array}$ & $\begin{array}{l}100 \mathrm{a} \\
100 a \\
100 a\end{array}$ \\
\hline Funguran & $\begin{array}{l}0.17{\mathrm{~g} 50 \mathrm{ml}^{-1}}_{0.33 \mathrm{~g} 50 \mathrm{ml}^{-1}} \\
0.50 \mathrm{~g} 50 \mathrm{ml}^{-1}\end{array}$ & $\begin{array}{l}100 a \\
100 a \\
100 a\end{array}$ & $\begin{array}{l}100 \mathrm{a} \\
100 \mathrm{a} \\
100 \mathrm{a}\end{array}$ & $\begin{array}{l}100 \mathrm{a} \\
100 \mathrm{a} \\
100 \mathrm{a}\end{array}$ \\
\hline Mancozeb & 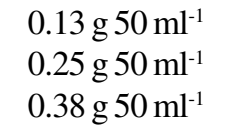 & $\begin{array}{l}100 \mathrm{a} \\
100 \mathrm{a} \\
100 \mathrm{a}\end{array}$ & $\begin{array}{l}100 \mathrm{a} \\
100 \mathrm{a} \\
100 \mathrm{a}\end{array}$ & $\begin{array}{l}100 \mathrm{a} \\
100 \mathrm{a} \\
100 \mathrm{a}\end{array}$ \\
\hline Sulphur 80 & $\begin{array}{l}0.09 \mathrm{~g} 50 \mathrm{ml}^{-1} \\
0.17 \mathrm{~g} 50 \mathrm{ml}^{-1} \\
0.26 \mathrm{~g} 50 \mathrm{ml}^{-1}\end{array}$ & $\begin{array}{l}15 \mathrm{~b} \\
22 \mathrm{~b} \\
20 \mathrm{~b}\end{array}$ & $\begin{array}{l}25 \mathrm{c} \\
43 \mathrm{~b} \\
25 \mathrm{c}\end{array}$ & $\begin{array}{l}28 \mathrm{c} \\
36 \mathrm{~b} \\
27 \mathrm{c}\end{array}$ \\
\hline Zamir & $\begin{array}{l}0.08 \mathrm{ml}^{5} 5 \mathrm{ml}^{-1} \\
0.15 \mathrm{ml}^{-1} \mathrm{ml}^{-1} \\
0.26 \mathrm{ml}^{-1} \mathrm{ml}^{-1}\end{array}$ & $\begin{array}{l}100 \mathrm{a} \\
100 \mathrm{a} \\
100 \mathrm{a}\end{array}$ & $\begin{array}{l}100 \mathrm{a} \\
100 \mathrm{a} \\
100 \mathrm{a}\end{array}$ & $\begin{array}{l}100 \mathrm{a} \\
100 \mathrm{a} \\
100 \mathrm{a}\end{array}$ \\
\hline
\end{tabular}

Means followed by same letters in a column are not significantly different at LSD (5\%) 

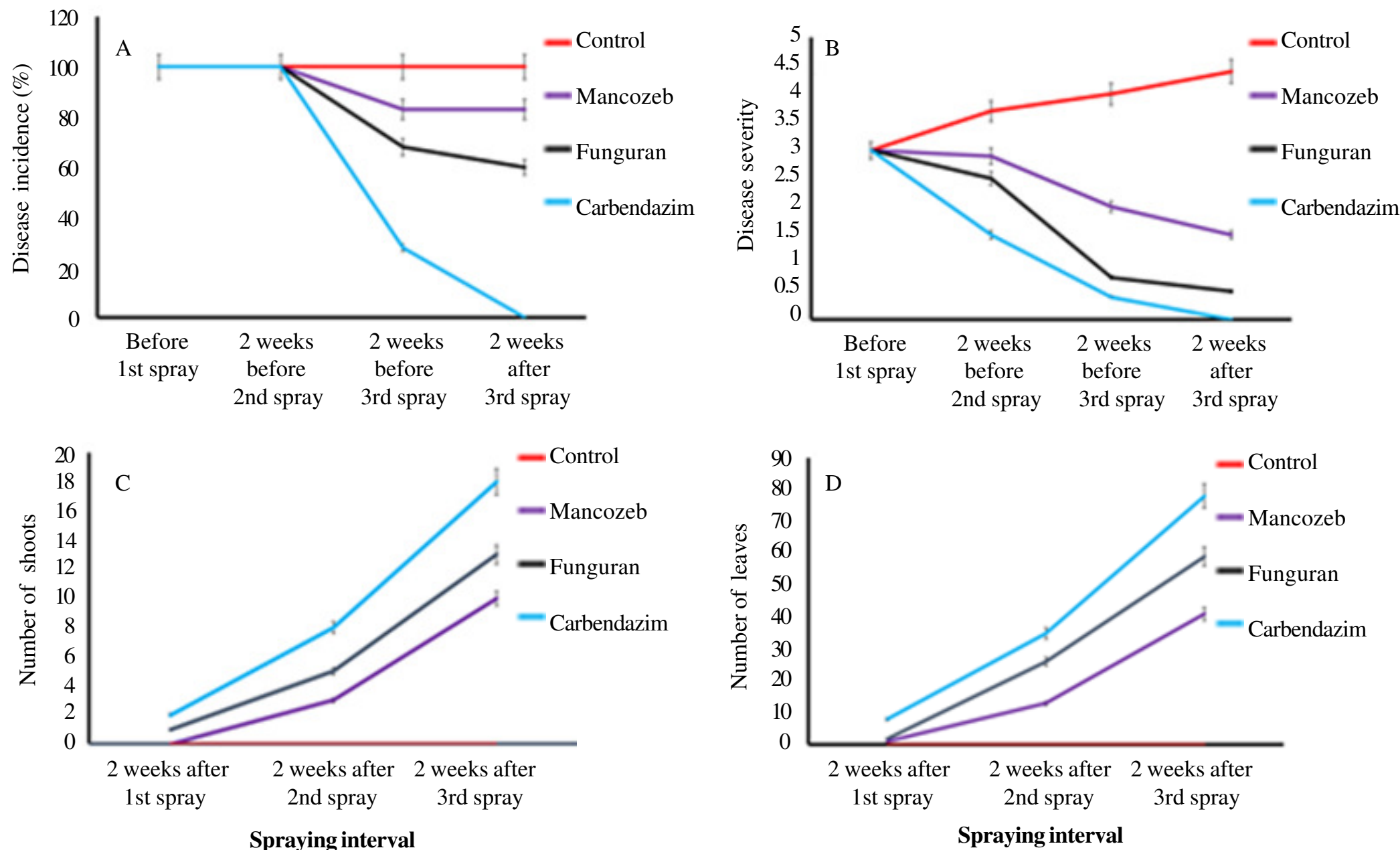

Figure 1. Effect of fungicidal spray on incidence (A), severity (B), shoot growth (C) and leaf growth (D) of mango tree decline disease. Vertical bars represent LSD (5\%). 
disease-trees sprayed with carbendazim and funguran, showed profuse vegetative (shoots and leaves) growth. However, mango trees treated with mancozeb produced less vegetative shoots and leaves. For the untreated (control) plants, the number of shoots and leaves production declined with time.

Aqueous extracts on growth of $L$. theobromae. The radial growth rates of the tested fungus in aqueous extracts of all the plants materials were commensurated with the sprayed concentration of the extracts (Tables 5 and 6). In the DPDA amended with aqueous extracts of $C$. odorata, radial growth rate in $1: 1 \mathrm{v} / \mathrm{v}$ dilution of the extract suppressed growth of $L$. theobromae by $50 \%$ in $72 \mathrm{hr}$ at mean growth rate of $0.86 \pm 0.68 \mathrm{~mm}$ per hour; whereas the fungus in the extract-free media covered the plate in $42 \mathrm{hr}$ at mean growth rate of $1.94 \pm 0.25 \mathrm{~mm}$ per hour.

As dilution increased, the biotoxins became less effective (Fig. 2A); a trend that was similar to the fungus growing on DPDA amended with varying dilutions $(1: 1-1: 10 \mathrm{v} / \mathrm{v})$ of the aqueous extract of $A$. indica. The highest concentration of the biotoxins reduced the vegetative growth in the fungus by $50 \%$ in $72 \mathrm{hr}\left(0.77 \pm 0.50 \mathrm{~mm} \mathrm{hr}^{-1}\right)$, with a general improvement growth of the fungus as dilution increased, but the growth in dilution up to 1:10 $\mathrm{v} / \mathrm{v}$ differed from that of the control plates (Fig. 2B). The seed extract of C. papaya was less potent against the pathogen (Fig. 2C; Table 5). With regard to the efficacy of the extracts in reducing the vegetative growth, $C$. odorata

TABLE 5. Influence of varying concentrations of the aqueous extracts of $C$. odorata leaves, $A$. indica leaves and Carica papaya seeds on the radial growth of $L$. theobromae at $28 \pm 1^{\circ} \mathrm{C}$ for $72 \mathrm{hr}$

\begin{tabular}{lccc}
\hline Dilutions of extract $(\mathrm{v} / \mathrm{v})$ & \multicolumn{3}{c}{ Mean growth rate $( \pm \mathrm{SE})\left(\mathrm{mm} \mathrm{hr}^{-1}\right)$} \\
\cline { 2 - 4 } & C. odorata & A. indica & Carica papaya \\
\hline Control & $1.94 \pm 0.25^{\mathrm{a}}$ & $1.94 \pm 0.25^{\mathrm{a}}$ & $1.94 \pm 0.25^{\mathrm{a}}$ \\
$1: 1$ & $0.86 \pm 0.68^{\mathrm{b}}$ & $0.77 \pm 0.50^{\mathrm{b}}$ & $1.24 \pm 0.46^{\mathrm{b}}$ \\
$1: 2$ & $1.02 \pm 0.42^{\mathrm{b}}$ & $0.88 \pm 0.47^{\mathrm{b}}$ & $1.47 \pm 0.42^{\mathrm{b}}$ \\
$1: 5$ & $1.06 \pm 0.13^{\mathrm{b}}$ & $1.08 \pm 0.46^{\mathrm{b}}$ & $1.64 \pm 0.43^{\mathrm{b}}$ \\
$1: 10$ & $1.25 \pm 0.50^{\mathrm{b}}$ & $1.58 \pm 0.47^{\mathrm{b}}$ & $1.78 \pm 0.37^{\mathrm{b}}$ \\
\hline
\end{tabular}

Means in the same column with the same alphabets are not statistically different $(\mathrm{P}<0.05)$

TABLE 6. Effect of plant materials aqueous extract on the vegetative growth of L. theobromae at 28 $\pm 1{ }^{\circ} \mathrm{C}$ for 5 days

\begin{tabular}{llll}
\hline Dilutions of extract $(\mathrm{v} / \mathrm{v})$ & \multicolumn{2}{c}{ Mean dry weight of mycelium $( \pm \mathrm{SE})(\mathrm{mg})$} \\
\cline { 2 - 4 } & C. odorata & A. indica & Carica papaya \\
\hline Control & $291.7 \pm 1.44^{\mathrm{a}}$ & $291.7 \pm 1.44^{\mathrm{a}}$ & $291.7 \pm 1.44^{\mathrm{a}}$ \\
$1: 1$ & $92.3 \pm 1.26^{\mathrm{b}}$ & $158.7 \pm 1.15^{\mathrm{b}}$ & $180.7 \pm 0.58^{\mathrm{b}}$ \\
$1: 2$ & $146.7 \pm 2.89^{\mathrm{b}}$ & $218.3 \pm 1.44^{\mathrm{b}}$ & $228.3 \pm 3.82^{\mathrm{b}}$ \\
$1: 5$ & $211.7 \pm 1.44^{\mathrm{b}}$ & $245.0 \pm 2.50^{\mathrm{b}}$ & $250.0 \pm 2.50^{\mathrm{b}}$ \\
$1: 10$ & $251.7 \pm 1.44^{\mathrm{b}}$ & $261.7 \pm 1.44^{\mathrm{b}}$ & $266.7 \pm 1.44^{\mathrm{b}}$ \\
\hline
\end{tabular}

Means in the same column followed by different alphabets are significant different at $\mathrm{P}<0.05$ 
Management of mango tree decline disease in Ghana
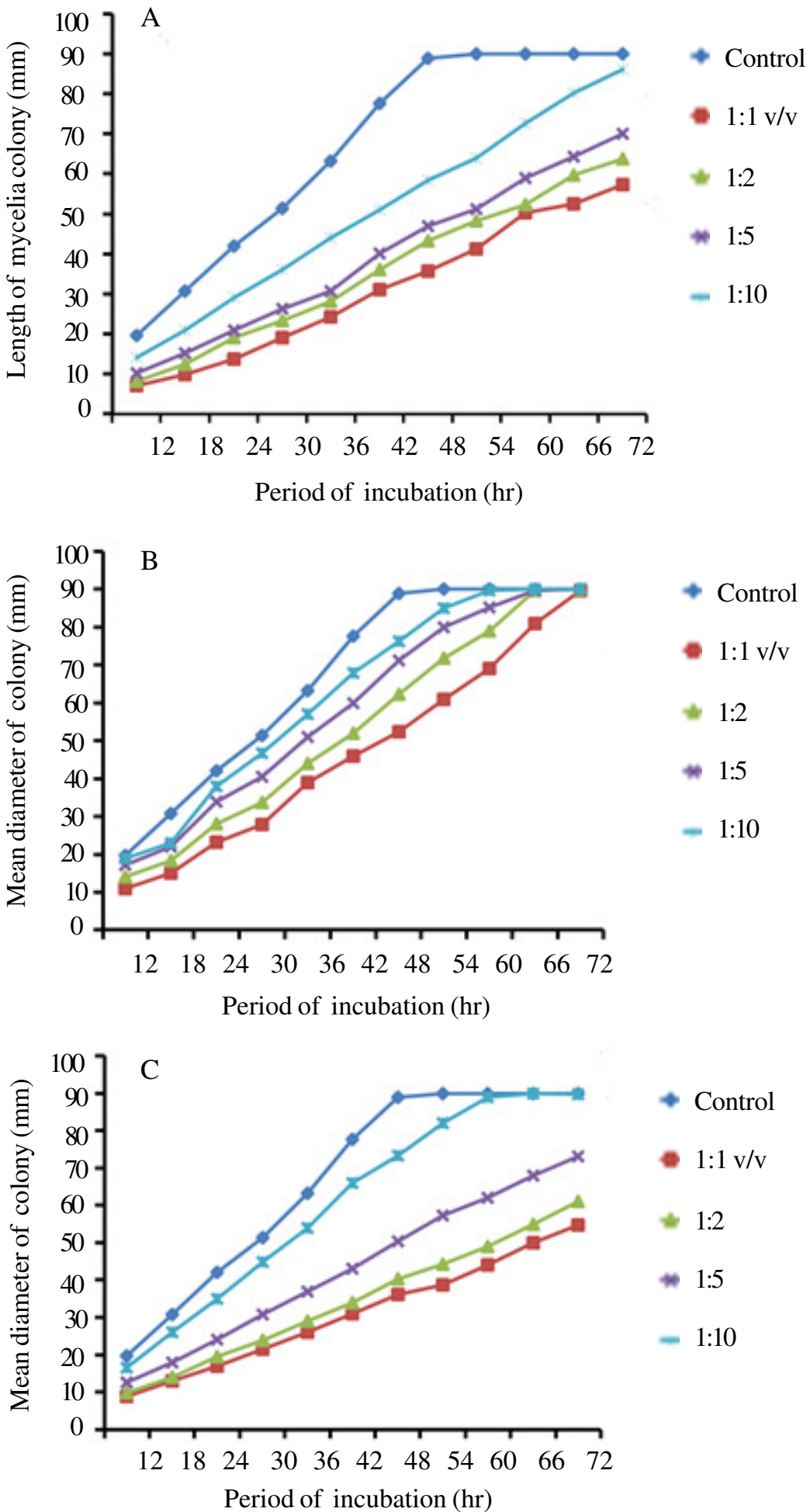

Figure 2. Influence of PDA amended with the indicated concentrations of aqueous extract of $C$. odorata (A), A. indica (B) and C. papaya (C) leaves on the radial growth of L. theobromae at $28 \pm 1$ ${ }^{\mathrm{o}} \mathrm{C}$. 
recorded the highest value; followed by $A$. indica and then C. papaya.

Vegetative growth and sporulation of $\boldsymbol{L}$. theobromae. Vegetative growth assessed in form of dry matter accumulation by $L$. theobromae was suppressed by the aqueous extracts of the tested plants at high concentrations (Table 6); with severe reductions in vegetative growth (Table 6 , Figs. 3A-C). Chromolaena odorata at 1:1 v/v concentration suppressed vegetative growth by $65 \%$ (Fig. 3A); although further dilution of the extract decreased its potency. Aqueous extract of $A$. indica at $1: 1 \mathrm{v} / \mathrm{v}$ dilution decreased dry weight of the pathogen by $50 \%$ (Fig. 3B); subsequent dilution up to $1: 10 \mathrm{v} / \mathrm{v}$ decreased the efficacy of the biotoxins. Similarly, the aqueous extract of $C$. papaya reduced vegetative growth of the pathogen by $40-45 \%$ in 5-days, with the final dry weight varying from that of the control (Fig. 3A-C). The aqueous extract with the highest efficacy was $C$. odorata, followed by $A$. indica and then $C$ papaya. In all the flasks, no spore (conidium) was detected after the 5-day period of growth, when a piece of the harvested mycelia mat was mounted and observed under a light microscope.

\section{DISCUSSION}

This study has highlighted fungicides and bioextracts that are most suitable for MTDD management, and can be rotated to avoid posing a threat to the agroecosystem. For the first time, we have evaluated six different fungicides and three bioextracts against $L$. theobromae to aid the development of ecologically sound Integrated Disease Management strategy against the MTDD in Ghana.

In the in vitro evaluation of the fungicides, the laboratory trial showed that all the fungicides, except sulfur 80, inhibit mycelia radial growth of $L$. theobromae, suggesting that both the tested contact and systemic fungicides may be effective in controlling the MTDD. However, carbendazim and funguran were more effective than the other fungicides. The ineffectiveness or low levels of suppression by sulfur 80 could be attributed to its active ingredients, and may thus not be suitable for area-wide management of the disease. Mancozeb was effective for controlling MTDD. In contrast, an earlier study concluded it to be less inhibitive to mycelial growth under in vitro conditions (Sahi et al., 2012). It is worth mentioning that our findings are based on simple laboratory tests, and a field comparison of the efficacy of the fungicides is necessary to confirm the present findings.

During the field evaluation of the pesticides, application of the fungicides at a two-weeks interval showed carbendazim to be the most effective in reducing the disease incidence and severity (Fig. $1 \mathrm{~A}$ and $1 \mathrm{~B}$ ). This is consistent with the study conducted by Baibakova et al. (2019), that fungicides inhibit rapid development of fungal pathogens, thereby reducing their ability to cause severe tissue damage which invariably increases leaf surface area for efficient photosynthesis. Similarly, Watkins et al. (1977) confirmed that a broad spectrum systemic fungicide is effective for reducing date palm disease incidence. Our results showed that to some extent, funguran reduced the incidence and severity of the mango decline disease. The fungicide (funguran) was also effective in suppressing the mango anthracnose disease in Ghana (Honger et al., 2015).

With regard to the effects of fungicidal spray on shoot and leaf growth, the study revealed that mango trees treated with carbendazim produced the highest new vegetative growth (shoots and leaves) (Fig. 1 $\mathrm{C}$ and $1 \mathrm{D}$ ). These findings are consistent with those of Muhammad et al. (2005), who reported that carbendazim was effective in inhibiting the mycelial radial growth under in vitro condition. The authors further indicated that carbendazim suppressed gum exudation, 

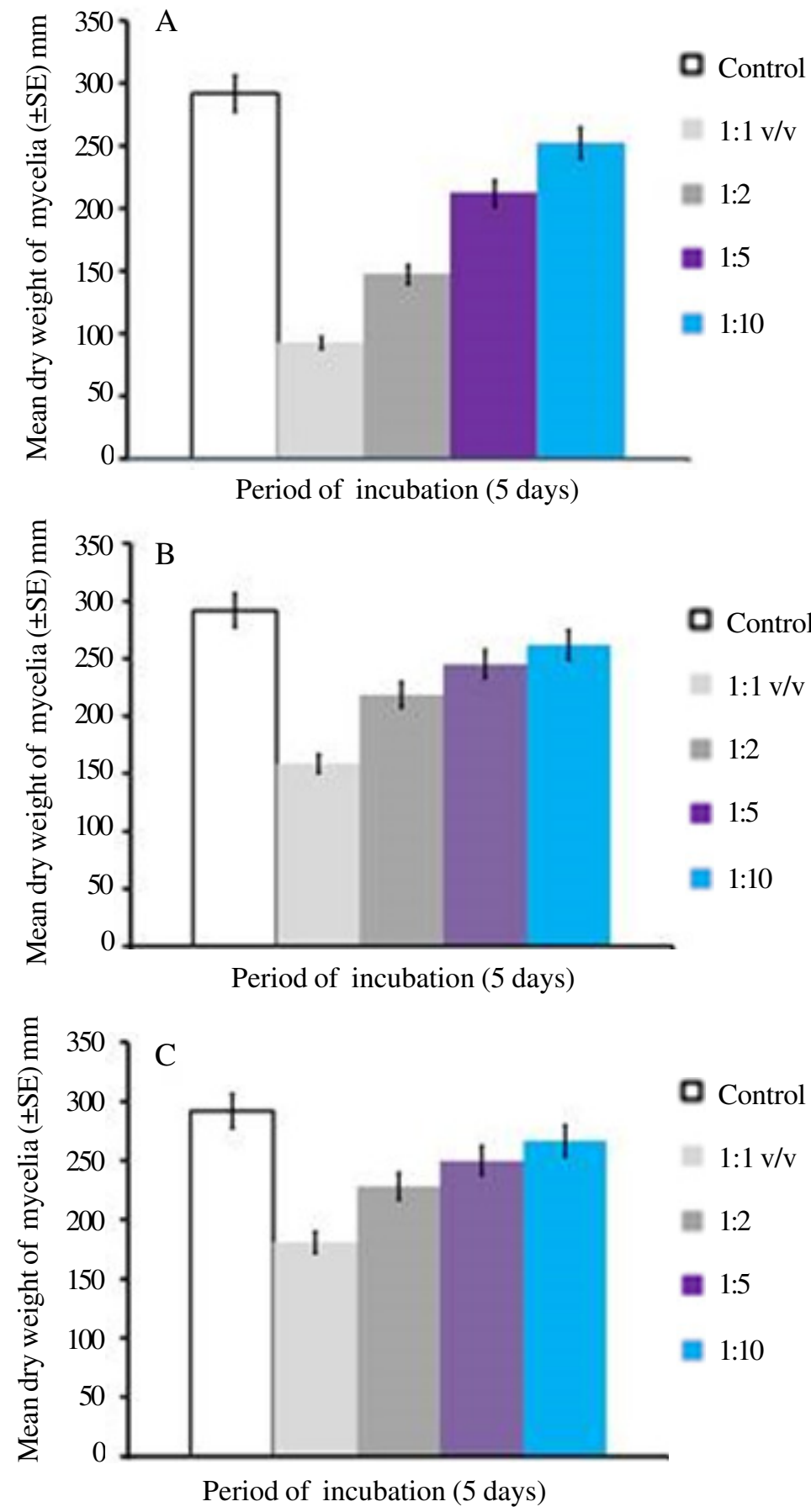

Figure 3. Influence of PDA amended with the indicated concentrations of aqueous extract of $C$. odorata (A), A. indica (B) and (C. papaya) leaves on the vegetative growth of L. theobromae at $28 \pm$ $1{ }^{\circ} \mathrm{C}$ for 5 days. 
dieback and wilting; but promoted vegetative growth of the plants. The effectiveness of carbendazim could be associated with its broad-spectrum systemic fungicide properties with protective and curative actions. Although mancozeb was ineffective in controlling the disease, with a marginal growth of vegetative parts (shoots and leaves) and gumming on the disease-trees, it performed better than the untreated mango trees. Mancozeb is a contact fungicide, and repeated applications at a shorter interval could help to control the disease (Honger, 2014). However, frequent pesticides application of fungicides may increase the chemical burden in the soil, leave poisonous residues in the fruits, and eventually have a detrimental effect on the environment and human health (Igbedioh, 1991; Forget, 1993). We found that proper sanitation (pruning), irrigation and fertiliser application with at least 3 -fortnightly sprays with Carbendazim could help to control the mango tree decline disease. This is consistent with that of Maloy (1993), who suggested that the integration of multiple farm practices with the aim of eliminating human and environmental health risk caused by chemicals used for controlling mango diseases as the most realistic alternative for solving the problem.

Biological control using natural plant products, presents a viable alternative in controlling plant diseases. The search for bioactive compounds from medicinal plants, and other angiosperms for biological control is crucial for the survival of the mango industry.

With respect to the aqueous extracts sprayed against the pathogen, our result demonstrated that compounds extracted from plants varied in their efficacy in inhibiting $L$. theobromae growth as the concentration of the bio toxins increased. The differences in fungitoxic activity observed in plant extracts may be due to differences in active ingredient potency, solubility of active compounds in the extraction medium (solvent), and the presence of inhibitors (Qasem and Abu-Blan, 1996;
Amadioha, 2001). Our finding corroborates that of Agyemang-Boateng (2016), who observed that at higher concentrations, aqueous plant extract of Plectranthus colerides suppressed the vegetative growth and prevented sporulation and pycnidial formation of $L$. theobromae under in vitro conditions. Our result is in agreement with Adejumo and Otuonye (2002), who reported that $C$. odorata at $5,7.5$ and $10 \%$ concentrations reduced the incidence of inflorescence blight disease in cashew. It is worth noting that the extracts' inhibition of spore germination is beneficial in the management of $L$. theobromae, the causal agent of mango tree decline disease in Ghana. However, the study showed that $C$. odorata extract was the most effective in inhibiting the mycelial radial growth of the fungus. The increasing incidence of the disease in Northern Ghana suggests the need to evaluate fungicides available in the Ghanaian market for the management of the disease.

\section{CONCLUSION}

This study showed that carbendazim combined with pruning, irrigation and fertiliser application is effective in controlling the disease in Ghana. In-vitro studies showed that the extract from $C$. odorata was the most successful in reducing mycelia growth of $L$. theobromae. Field trials are recommended to further evaluate and ascertain the efficiency of the botanicals in controling the mango tree decline disease. This will help to formulate new, safe and ecologically friendly fungicides from the tested plant extracts for MTDD management in Ghana.

\section{ACKNOWLEDGEMENT}

The authors are grateful to the Office of Research and Innovation Development (ORID), a research support arm of the University of Ghana, Legon, for sponsoring this research work. 


\section{REFERENCES}

Ablomerti, F.K. 2016. Aetiology, economic importance and control of mango (Mangifera indica L.) tree decline disease in Northern Region of Ghana. MPhil. Thesis, Department of Crop Science, University of Ghana, Legon, Ghana. 106pp.

Adejumo, T.O. and Otuonye, A.H. 2002. The use of botanicals in the control of inflorescence blight disease of cashew, Anacardium occidentale. Nigeria Journal Sciences 36(1):75-80.

Agyeman-Boateng, S. 2016. Preliminary evaluation of the influence of biotoxins of the aqueous extract of Plectranthus coleiodes on vegetative growth of three plant pathogenic fungi of cocoa (Theobromae cacao L.) and mango (Mangifera indica L.). BSc. (Hons) Dissertation. Department of Plant and Environmental Biology, University of Ghana, Legon, Ghana. 51pp.

Al Adawi, A.O., Deadman, M.L., Al Rawahi, A.K., Al Maqbali, Y.M., Al Jahwari, A.A., Al Saadi, B.A., Al Amri, I.S. and Wingfield, M.J. 2006. Etiology and causal agents of mango sudden decline disease in the Sultanate of Oman. European Journal of Plant Pathology 116:247-254.

Al-Adawi, A.O., Deadman, M.L., Al-Rawahi, A.K., Khan, A.J. and Al-Maqbali, Y.M. 2003. Diplodia theobromae associated with sudden decline of mango in the Sultanate of Oman. Plant Pathology 52(3):419.

Akurugu, G.K., Olympio, N.S., Ninfaa, D.A. and Karbo, E.Y. 2016. Evaluation of postharvest handling and marketing of mango (Mangifera indica) in Ghana: A case study of northern region. Journal of Research in Agriculture and Animal Science 4(5):2321-9459.

Amadioha, A.C. 2001. Fungitoxic effects of some leaf extracts against Rhizopus oryzae causing tuber rot of potato. Archives of Phytopathology and Plant Protection 33(6):499-507.
Baibakova, E.V., Nefedjeva, E.E., SuskaMalawska, M., Wilk, M., Sevriukova, G.A. and Zheltobriukhov, V.F. 2019. Modern fungicides: Mechanisms of action, fungal resistance and phytotoxic effects. Annual Research and Review in Biology 32(3):116.

Banson, K.E. and Egyir-Yawson, A. 2014. Socio-economic impact of fruit flies control in mango production in Ghana, evidence from "Manya Krobo". Journal of Agriculture Science and Technology ISSN 1939-1250:454-463.

Bradley, C.A., Lame, H.A., Endres, G.J., Henson, R.A., Hanson, B.K., McKay, K.R., Halvorson, M., LeGare, D.G. and Porter, P.M. 2006. Efficacy of fungicides for control of Sclerotinia stem rot of canola. Plant Disease 90(9):1129-1134.

Coleman, S.R. 2016. Survey of the mango tree decline disease, characterisation of the causal agent and some aspects of the biocontrol of the pathogen in Ghana. Master of Philosophy thesis, University of Ghana, Legon, Ghana. 234pp.

Evans, E.A., Ballen, F.H. and Siddiq, M. 2017. Mango production, global trade, consumption trends and postharvest processing and nutrition. Handbook of Mango Fruit; John Wiley \& Sons: Chichester, UK. pp. 1-16.

Forget, G. 1993. Balancing the need for pesticides with the risk to human health. In: Impact of pesticide use on health in developing countries. Proceedings of a Symposium held in Ottawa, Canada, 1720 September 1990. IDRC, Ottawa, ON, CA. 16pp.

Groth, D.E., Rush, M.C. and Lindberg, G.D. 1990. Foliar fungicides for control of rice diseases in the United States. In: Pest management in rice. Springer, Dordrecht. pp. 31-52.

Gurjar, M.S., Ali, S., Akhtar, M. and Singh, K.S. 2012. Efficacy of plant extracts in plant disease management. Agricultural 
Sciences 3:425-433. doi 10.4236/ as.2012.33050

Honger, J.O. 2014. Characterisation of the causal agent of mango anthracnose disease in Ghana. Doctoral dissertation, University of Ghana, Ghana. 199pp.

Honger, J.O., Offei, S.K., Oduro, K.A. and Odamtten, G.T. 2015. Chemical control of mango anthracnose disease in Ghana. Ghana Journal of Agricultural Science 49(1):15-28.

Honger, J.O., Coleman, S.R., Ablormeti, F.K., Cornelius, E.W., Owusu, E. and Odamtten, G.T. 2018. The aetiology, incidence and severity of mango tree decline disease in Ghana. Ghana Journal of Science 58:1322.

Igbedioh, S.O. 1991. Effects of agricultural pesticides on humans, animals, and higher plants in developing countries. Archives of environmental health. An International Journal 46(4):218-224.

Javaid, A., Shoaib, A. and Akhtar, N. 2008. In vitro chemical control of Botryodiplodia theobromae, the cause of Dying Back disease of mango. Pakistan Journal of Phytopathology 20(2):195-199.

Jayasena, K.W., Loughman, R. and Majewski, J. 2002. Evaluation of fungicides in control of spot-type net blotch on barley. Crop Protection 21(1):63-69.

Kiran, B., Lalitha, V. and Raveesha, K.A. 2010. Screening of seven medicinal plants for antifungal activity against seed borne fungi of maize seed. African Journal of Basic Applied Sciences 2(3-4):99-103.

Krishnan, A.G., Nailwal, T.K., Shukla, A. and Pant, R.C. 2009. Mango (Mangifera indica L.) malformation an unsolved mystery. Researcher 1(5):20-36.

Khuhro, R.D., Nizamani, S.M., Abbasi, Q.D., Solangi, G.S. and Jiskani, M.M. 2005. Mango tree mortality due to Asian ambrosia beetle, Xylosandrus crassiusculus (Coleoptera: Scolytidae). Pakistan Journal of Agricultural Engineering, Vetenary Science 21(1):39- 42.
Maloy, O.C. 1993. Plant Disease Control: Principles and Practices. John Wiley and Sons, INC. NY. pp. 303-318.

Masood, A., Salman, M. and Saeed, S. 2014. Fungicide injection, an efficient management technique of mango sudden death disease in Punjab, Pakistan. Pakistan Journal of Phytopathology 26(2):259-263.

Masood, A., Saeed, S, Erbilgin, N. and Kwon, Y.J. 2010. Role of stressful mango host conditions in attraction and colonization by the mango bark beetle, Hypocryphalus mangiferae Stebbing (Coleoptera: Curculionidae: Scolytinae) and in the symptom development of quick decline on mango trees in Pakistan. Entomology Research 40:317-327.

Muhammed, A., Aman, U.M., Ahmad, S.K. and Nazir, J. 2005. Potential of fungicides and plant activator for postharvest disease management in mangoes. International Journal of Agricultural and Biology 13:671-676. ISSN Print: 1560-8530; ISSN Online: 1814-9596 11-096/AWB/2011/135-671-676 http://www. fspublishers.org

Qasem, R. and Aau Blan, H.A. 1996. Fungicidal activity of some common weed extracts against different plant pathogenic fungi. Journal of Phytopathology 144(3):157161.

Okemo, P.O., Bais, H.P. and Vivanco, J.M. 2003. In vitro activities of Maesa lanceolata extracts against fungal plant pathogens. Fitoterapia 74(3):312-316.

Okorley, E.L., Acheampong, L. and Abenor, M.T. 2014. The current status of mango farming business in Ghana: A case study of mango farming in the Dangme West District. Ghana Journal of Agricultural Science 47(1):73-80.

Panhwar, A., Nizamani, S.M., Khuhro, R.D., Abbasi, Q.D. and Muhammad, M.J. 2007. Impact of mango sudden decline disease in Sindh Pakistan. Proceeding of the International Symposium on prospects of horticultural industry in Pakistan. pp.195200. 
Ploetz, R.C., Benscher, D., Vazquez, A., Colls, A., Nagel, J. and Schaffer, B. 1996. A reevaluation of mango decline in Florida. Plant Disease 80:664-668.

Ramos, L.J., Davenport, T.L., McMillan, Jr. R.T. and Lara, S.P. 1997. The resistance of mango (Mangifera indica) cultivars to tip dieback disease in Florida. Plant Disease 81(5):509-514.

Saeed, E.E., Sham, A., AbuZarqa, A., A., Al Shurafa, K.S., Al Naqbi, T., Iratni, R.F. and AbuQamar, S. 2017. Detection and management of mango dieback disease in the United Arab Emirates. International Journal of Molecular Sciences 18(10): 2086.

Saeed, S. and Masood, A. 2008. Association of Bark beetle Hypocrphalus mangiferae Stebbing (Coleptera: Scolytidae) with pathogens Ceratocystis fimbriata and Phompsis sp. in relation to mango sudden death in Pakistan. International conference, 93rd ESA Annual Meeting, Milwaukee, Wisconsin August 3-8, 2008, USA.

Sahi, S.T., Habib, A., Ghazanfar, M.U. and Badar, A. 2012. In vitro evaluation of different fungicides and plant extracts against Botryodiplodia theobromae, the causal agent of quick decline of mango. Pakistan Journal of Phytopathology 24(2):137-142.

Sales, M.D.C., Costa, H.B., Fernandes, P.M.B., Ventura, J.A. and Meira, D.D. 2016. Antifungal activity of plant extracts with potential to control plant pathogens in pineapple. Asian Pacific Journal of Tropical Biomedicine 6(1):26-31.

Schaffer, B. 1994. Mango decline. In: Compendium of tropical fruit diseases. Ploetz, R.C., Zentmyer, G.A., Nishijima, W. Rohrbach, K. and Ohr, H.D. (Eds.). APS press, St. Paul. 43pp.
Shahbaz, M., Iqbal, Z., Saleem, A. and Anjum, M.A. 2009. Association of Lasiodiplodia theobromae with different decline disorders in mango (Mangifera indica L.). Pakistan Journal Botany 41(1):359-368.

Simone, G.W. 1999. Disease control in mango (Mangifera indica). Plant Pathology Department Document PDMG-V3-22. Florida Cooperative Extension Service, Institute of Food and Agricultural Sciences, University of Florida, USA.

Tegegne, G., Pretorius, J.C. and Swart, W.J. 2008. Antifungal properties of Agapanthus africanus L. extracts against plant pathogens. Crop Protection 27(7):10521060.

Tharanathan, R.N., Yashoda, H.M. and Prabha, T.N. 2006. Mango (Mangifera indica L.), "The king of fruits": An overview. Food Reviews International 22(2):95-123.

Wanyera, R., Macharia, J.K., Kilonzo, S.M. and Kamundia, J.W. 2009. Foliar fungicides to control wheat stem rust, race TTKS (Ug99), in Kenya. Plant Disease 93(9):929932.

Watkins, J.E., Littlefield, L.J. and Statler, G.D. 1977. Effect of the systemic fungicide on the development Puccinia recondita f.sp. tritici in wheat. Phytopathology 67:985980.

Yamaguchi, I. 1982. Fungicides for control of rice blast disease. Journal Pesticide Science 7(3):307-316.

Yidu, P.K.D. 2015. The political economy of export crops in Ghana: A study of the mango industry. Doctoral dissertation, University of Ghana, Ghana. 278pp.

Zakari, A.K. 2012. Ghana national mango study: Support of the PACT II program and the international trade centre (Geneva). $57 \mathrm{pp}$. 